\title{
If you Give Shareholders Power, do they Use it? An Empirical Analysis
}

\author{
by \\ YAIR LISTOKIN*
}

\begin{abstract}
Many commentators assert that enhanced shareholder power is a promising cure for corporate governance ills. This paper empirically examines the impact of differential amounts of shareholder power on governance arrangements. When U.S. states enacted statutory antitakeover protections in the 1980s, the states differed in the power granted to shareholders to opt out of the antitakeover protections without agreement by the board of directors. These differences in shareholder power are associated with little change in governance arrangements. The results suggest that simply altering shareholder power without changing other governance mechanisms is unlikely to lead to widespread changes in corporate governance. (JEL: G 34, K 22, D 72)
\end{abstract}

\section{Introduction}

Many corporate governance observers believe that enhanced shareholder democracy and power is a promising cure for governance ills (BEBCHUK [2005]). ${ }^{1}$ Their argument is straightforward; principal-agent conflicts imply that management does not always pursue value maximizing governance arrangements. By "allowing shareholders to initiate and vote to adopt changes in the company's basic corporate governance arrangements," the inefficiencies associated with the principal-agent problem will be mitigated (BEBCHUK [2005, p. 836]).

Others disagree. Opponents of shareholder power argue that such power would be inefficient and that investors would make "little use of the powers" (BAINBRIDGE [2006, p. 1751]). ${ }^{2}$ Instead, shareholder power will be used primarily by minor-

* Associate Professor of Law, Yale Law School. I thank Ian Ayres, Robert Daines, Simon Deakin, Daniel Ho, Jonathan Klick, Roberta Romano, Alexander Stremitzer, and participants in JITE's Kloster Eberbach conference for helpful comments and discussions and Ian Masias for excellent research assistance. All errors are my own.

1 See also BUXBAUM [1985] advocating greater shareholder participation and power, DENT JR. [1989].

2 See also EASTERBROOK AND FISCHEL [1991, p. 82-89], explaining why shareholders should and do take a quiet role in corporate decisionmaking. 
ity shareholders seeking publicity rather than value maximization (BAINBRIDGE [1992]).

The debate ultimately rests on an empirical question - can shareholders effectively use enhanced power to improve governance arrangements? If shareholders can use democracy to improve governance, then the resulting benefits likely outweigh the costs of expanding the set of corporate decision makers. If greater shareholder power does not lead to changes in corporate governance and power is exploited for inefficient purposes, however, then shareholder power should not be increased.

In spite of the empirical nature of the question, there are few studies of whether shareholders use greater power to implement changes in governance arrangements.

This paper studies this question by examining the impact of variations in shareholder power. In the middle and late 1980s, one of the most salient questions of corporate law regarded the efficiency of various state anti-takeover statutes. Many states passed default statutes, such as control share acquisition, business combination, and fair price statutes, that hindered the ability of an acquirer to effectively take control of a target corporation. While the language of the antitakeover statutes was similar, they differed in one important respect - the degree to which shareholder democracy could alter these antitakeover defaults. Some states required charter amendments to opt out of the default antitakeover provisions, restricting the ability of shareholder democracy to change governance arrangements because charter amendments require board approval. Other states, by contrast, allowed opting-out via shareholder initiated bylaw amendments, thereby enabling shareholder democracy to alter the default rule without managerial acquiescence.

If greater shareholder power enables shareholders to optimally adjust governance regimes, then the variation in opt-out procedures (also known as altering rules) (charter amendment v. bylaw) should lead to differences in antitakeover statute opt-out rates, other things equal.

Corporate opt-out rates show that this is not the case, however. Opt-out rates for anti-takeover statutes are very low in all states and are independent of the opt-out mechanism (DECONINCK [2005]). Granting greater shareholder power by allowing shareholders to unilaterally opt out of a statutory governance arrangement via bylaw does not lead to higher corporate opt-out rates compared with companies in states that require board approved charter amendments.

Moreover, the low opt-out rates from the antitakeover statutes cannot simply be attributed to the universal desirability of the statutes - most companies in states with no antitakeover statute or with opt-in statutes generally do not choose to write such protection into their charter (LISTOKIN [2009]).

The results indicate that increasing shareholder power by enabling shareholders to alter governance terms unilaterally via bylaw amendment does not cause shareholders to significantly change governance terms. This may be the result of two causes. One possibility is that corporations arrive at efficient governance arrangements independent of shareholders' ability to alter governance. The marked difference in antitakeover protection rates across states with different default laws casts doubt on this explanation. So does the fact that the passage of control share acquisition 
statutes and business combination statutes is associated with a decline in stock market value for companies incorporated in states passing the statutes (KARPOFF AND MALATESTA [1989]). ${ }^{3}$ Given these sources of evidence, a more likely explanation of the results is that antitakeover statutes allow management an inefficient level of power, but that granting shareholders the power to alter governance unilaterally does not provide shareholders with enough power and/or incentives to go about changing the inefficient terms.

Anecdotal evidence also contradicts the arguments of proponents of the status quo, who argue that increased shareholder power will benefit special interests such as advocacy groups with little interest in maximizing corporate value and lead to widespread inefficiencies. The increase in shareholder power associated with the ability to opt out of antitakeover statutes via bylaw does not appear to have been associated with any such behavior by special interests. Thus, the empirical evidence suggests that both the benefits and the costs of increased shareholder power may be overstated by the protagonists of the shareholder power debate.

This paper proceeds as follows. Section 2 examines the literature on optimal shareholder power in more detail. Section 3 briefly describes the antitakeover statutes examined in the paper. Section 4 describes the data and presents summary statistics, while section 5 discusses the appropriate regression specification. Section 6 discusses and interprets the regression analysis. Section 7 concludes.

\section{Should Shareholder Power be Expanded?}

Most corporate governance arrangements derive from two sources - corporate charters and the state of incorporation's corporate laws (BEBCHUK [2005]). To amend a corporation's charter, state law requires board initiation and board submission to a shareholder vote of any proposed amendments. ${ }^{4}$ To alter the state of incorporation, a company commonly merges with a shell corporation incorporated in the desired state (BEBCHUK [2005]). To complete the merger, the board must initiate a shareholder vote (BEBCHUK [2005]).

As a result, shareholders have little say over the basic governance arrangements of a corporation. Any major changes in these arrangements require board approval. Critics state that this is inefficient. If a governance arrangement is inefficient but suits the board of directors, there will be almost no way to change it because any change initiated by shareholders must be approved by the board (BEBCHUK AND HAMDANI [2002]). Bebchuk provides a specific statutory example of such a scenario - Delaware's antitakeover statute. ${ }^{5}$ Bebchuk asserts that management has no incentive to opt out of the statute because it protects management. Shareholders might

3 The event study evidence also casts doubt on explanations of differential opt-out rates being caused by separating equilibria associated with signaling models.

4 Del. Code Ann. Tit. 8 Sec. 242(b).

5 Beвснuк [2005, p. 862], discussing Del. Code Ann. tit. 8, § 203 (1989). 
want to opt out, but they cannot because the statute requires a charter amendment to opt out and charter amendments require board approval (BEBCHUK [2005]).

Critics of the status quo want to expand shareholder power so that inefficient arrangements can be altered by shareholders without management approval. There are several ways this can be accomplished. One mechanism to increase shareholder power is to expand the use of bylaws in corporate governance. ${ }^{6}$ Bylaw amendments may be unilaterally initiated by shareholders, but at present the ability of bylaws to alter governance arrangements is quite limited (HAMERMESH [1998]). If the scope of bylaw amendments is expanded as urged by BEBCHUK [2005], however, then shareholders will be able to alter governance arrangements more easily. A second means to expand shareholder power is to allow shareholders to unilaterally initiate and approve charter amendments (BEBCHUK [2005]). Because charter amendments enable corporations to specify their own governance arrangements and alter state default arrangements, allowing unilateral shareholder charter amendments would similarly enable shareholder to independently alter governance arrangements.

With reference to Delaware's Antitakeover Statute, BEBCHUK AND HAMDANI [2002] have suggested that the Delaware antitakeover statute would have been much less pernicious if it would have allowed opting-out via bylaw. Bylaw opt-out would have allowed shareholders to unilaterally opt out of the statute's protections.

Expanding bylaw's scope or shareholder's power to amend the corporate charter has some obvious benefits in terms of reducing principal-agent problems. These proposals may also have considerable costs, however. As Bainbridge explains

"Active investor involvement in corporate decisionmaking seems likely to disrupt the very mechanism that makes the widely held public corporation practicable: namely, the centralization of essentially nonreviewable decisionmaking authority in the board of directors. The chief economic virtue of the public corporation is not that it permits the aggregation of large capital pools, as some have suggested, but rather that it provides a hierarchical decisionmaking structure well-suited to the problem of operating a large business enterprise with numerous employees, managers, shareholders, creditors, and other constituencies. In such an enterprise, someone must be in charge: 'Under conditions of widely dispersed information and the need for speed in decisions, authoritative control at the tactical level is essential for success."” (BAINBRIDGE [2006, p. 1749])

Moreover, many question the utility of allowing shareholders to unilaterally opt out of governance arrangements. Although enabling unilateral opt-out eliminates one impediment to shareholder activity, there are still many other hindrances. For example, Romano argues, in contrast to Bebchuk, that bylaw opt-outs will be ineffective in the state antitakeover statute context because of shareholder free-rider problems (ROMANO [1993, pp. 56]). ${ }^{7}$

6 For a comprehensive discussion of the issue, see HAMERMESH [1998]. See also COFFEE JR. [1997] examining the question of whether bylaws can repeal poison pills.

7 BAINBRIDGE [2006] also argues that other costs of shareholder activism mean that expanding shareholder power will not lead to a meaningful reduction in principal agent costs. 
Whatever the costs of expanded shareholder power, it is clear that there are largescale disagreements about its potential benefit. Supporters of expanded shareholder power assert that when shareholders can make unilateral changes, governance arrangements will change substantially. Opponents, however, claim that such changes will make little practical difference and simply complicate the governance process. The remainder of this paper attempts to test these competing assertions with data from corporate opt-out rates from state antitakeover statutes.

\section{State Antitakeover Statutes}

Following the Supreme Court's decision in CTS Corp. v. Dynamics Corp. of America upholding the state of Indiana's control share acquisition statutes, many states passed a number of different antitakeover statutes in the late 1980s (ISAACS [2004]). The large majority of these statutes were passed as default rules. These statutes hindered hostile bidders from easily obtaining control of a target corporation. This paper focuses on two types of popular antitakeover statutes, Business Combination statutes, and Control Share Acquisition statutes. ${ }^{8}$ State passage of both types of statute was associated with a decrease in market value for firms incorporated in that state (KARPOFF AND MALATESTA [1989]). Because the debate about corporate law altering rules focuses on shareholder adopted bylaws, companies in states that allowed board approved bylaws but not shareholder approved bylaws are excluded from the "bylaw" category.

Corporations could (and did) obtain CSA and business combination protection without statutes by writing such provisions directly into their charters or bylaws.

\subsection{Business Combination Statutes}

Business combination statutes, also known as "freeze-out" statutes, prohibit certain types of transactions (such as mergers or asset sales) between a large shareholder and a target company for a multi-year period after the large shareholder's stake exceeds a pre-specified amount. Board approval can enable the transactions to move forward during the prohibited period. Business combination statutes prevent bidders from obtaining the full benefit of their acquisition for a long period following the initial acquisition, and thereby deter bids. Many business combination statutes were passed in conjunction with fair price statutes.

Twenty-eight states enacted business combination default laws. The altering rule for these statutes varied considerably. 17 states allowed opting-out through bylaw amendments, while 11 required charter amendments for a company to opt out. The voting threshold for opting out also varied widely. While 18 states required a simple majority of outstanding shares to approve the bylaw or charter amendment necessary

8 Because fair price statutes were often passed in concert with business combination statutes, this paper focuses attention on business combination statutes exclusively. For more detail on fair price statutes, see LisTOKIN [2009]. 
for opting out, 6 states required two-thirds supermajorities and 3 states required even greater supermajorities. ${ }^{9}$ The states also varied in the speed with which an opt-out became effective. Ten states allowed the statutory opt-out to become effective as soon as the required bylaw or charter was passed. 12 states, however, delayed the effectiveness of the opt-out for one year, while the remaining states had even longer delays. ${ }^{10}$

\subsection{Control Share Acquisition Statutes}

Control share acquisition statutes provide that acquisition of a controlling block of shares does not ensure voting control. This deters the acquisition of control blocks by bidders because the bidders cannot be confident that their control can ever be exercised.

Indiana's control share acquisition (CSA) statute, at issue in CTS, is representative. The statute stipulates that the acquirer of 20,33 , or $50 \%$ of a company's shares must obtain the approval of a majority of the disinterested shares before the acquirer can exercise voting rights of the control stake. If voting rights fail to be approved, the company can reacquire the shares from the bidder at the market price.

Twenty-seven states enacted CSA default statutes. Eighteen allowed opting-out through changes to the bylaws, seven required charter amendments, and two states allowed the board to opt out via bylaw but otherwise required charter amendments for opting out. ${ }^{11}$ With one exception, all of these statutes require the vote of a majority of the shares outstanding to opt out, and impose no delay on opting-out after a vote.

\section{Data and Summary Statistics}

The Investor Responsibility Research Center (IRRC), now part of RiskMetrics, gathers biennial data on a myriad of antitakeover features for a large group of companies in its Corporate Takeover Defense Database. This data includes information on the existence of poison pills, classified boards, and golden parachutes, among many other provisions. The dataset includes information on whether a company is incorporated in a state that has enacted a default law fair price, business combination, or control share acquisition statute, and whether a company has opted out of the statute. ${ }^{12}$

The IRRC data was supplemented with data from several other sources. The data on each company from IRRC was matched with detailed company level data from

\footnotetext{
9 In the data analysis that follows, the states that allow bylaw opt-out via different majorities are lumped together in the bylaw opt-out category. The supermajority requirements make no observable difference to opt-out rates.

10 In the data analysis that follows, the states that delayed the effectiveness of an opt-out are lumped together with states that did not impose such a delay. The difference in delay for opt-out effectiveness makes no observable difference to opt-out rates.

11 States that only allow board bylaw opt-out are excluded from the analysis.

12 For more details about the dataset, see GOMPERS, ISHII, AND METRICK [2003].
} 
Compustat and CRSP. ${ }^{13}$ Initial CRSP appearance dates were used to determine if a company was publicly traded when antitakeover statutes were passed. Finally, additional data on the nature of each state's altering rule, such as whether or not a bylaw or charter amendment was needed to opt out of the statute, the majority necessary to opt out, and whether or not opt-outs were subjects to delay, was obtained from the statutes as well as the detailed descriptions of the antitakeover laws in IRRC's series on State Takeover Laws (ISAACS [2004]). With respect to the bylaw/charter distinction, it is important to note that some states (e.g. PA) allowed opt-out via a bylaw amendment passed by the board of directors, but not by the shareholders. For purposes of shareholder power, the board requirement makes the PA statute more similar to a statute requiring charter amendment opt-out than bylaw amendment opt-out. ${ }^{14}$ As a result, the PA opt-out is treated as requiring charter opt-out.

Companies generally choose between two possibilities for their state of incorporation - Delaware or their principal place of business (DAINES [2002]). Because Delaware firms are thus "different" from firms that incorporate in their place of business, the empirical analysis below generally displays results including and excluding companies incorporated in Delaware.

Table 1 presents summary statistics. ${ }^{15} 20 \%$ of all companies, and $50 \%$ of all companies not incorporated in Delaware, enjoy CSA protection, while $89 \%$ of companies and $78 \%$ of non Delaware companies, enjoy business combination protection. Note that almost all of these companies are protected via statute rather than "do-ityourself" charter or bylaw amendment. Companies incorporated in states without CSA statutes, who must enact their own amendment, enjoy CSA protection less than $1 \%$ of the time, while companies incorporated in states without BC statutes, who also must enact their own amendment, enjoy BC protection less than $5 \%$ of the time.

With respect to both statutes, most companies incorporated in states with antitakeover statutes can opt out of the statute via bylaw amendment, granting enhanced shareholder power. A non trivial number (7.5\% of companies in non Delaware CSA states and $25 \%$ of companies in non Delaware BC states) must opt out by charter, meaning that amendment can only take place with board approval. Companies that went public after all the statutes were passed have lower rates of CSA protection and are more likely to be found in bylaw opt-out states than the average company, though the differences are not overly large.

13 Imperfect merging and missing data mean that data analysis using the Compustat data relies on fewer observations than other specifications.

14 Charter amendments, unlike board passed bylaws, always need shareholder approval, creating a technical distinction between board passed bylaws and charter amendments. There is no case, however, of a board proposing to opt out of an antitakeover statute and the shareholders refusing.

15 Because data from the same firm is extremely highly correlated (nearly one), all data analysis includes only one observation per firm to avoid understating standard errors. 
Table 1

Summary Statistics

\begin{tabular}{|c|c|c|c|}
\hline & All companies & $\begin{array}{l}\text { Non } \\
\text { Delaware } \\
\text { companies }\end{array}$ & $\begin{array}{l}\text { Companies } \\
\text { going public } \\
\text { after } 1992\end{array}$ \\
\hline Percent of total companies & $100 \%$ & $40 \%$ & $37 \%$ \\
\hline $\begin{array}{l}\text { Proportion covered by } \\
\text { CSA antitakeover provision }\end{array}$ & 0.20 & 0.50 & 0.13 \\
\hline $\begin{array}{l}\text { Proportion covered by } \\
\text { bus. comb. antitakeover provision }\end{array}$ & 0.89 & 0.78 & 0.88 \\
\hline $\begin{array}{l}\text { Proportion of companies } \\
\text { incorporated in states with } \\
\text { CSA statute alterable by } \\
\text { bylaw amendment }\end{array}$ & 0.17 & 0.44 & 0.11 \\
\hline $\begin{array}{l}\text { Proportion of companies } \\
\text { incorporated in states with } \\
\text { CSA statute alterable by } \\
\text { charter amendment }\end{array}$ & 0.029 & 0.075 & 0.016 \\
\hline $\begin{array}{l}\text { Proportion of companies } \\
\text { incorporated in states with } \\
\text { bus. comb. statute alterable by } \\
\text { bylaw amendment }\end{array}$ & 0.774 & 0.43 & 0.85 \\
\hline $\begin{array}{l}\text { Proportion of companies } \\
\text { incorporated in states with } \\
\text { bus. comb. statute alterable by } \\
\text { charter amendment }\end{array}$ & 0.099 & 0.25 & 0.051 \\
\hline $\begin{array}{l}\text { Proportion covered by } \\
\text { poison pill }\end{array}$ & 0.54 & 0.54 & 0.49 \\
\hline Proportion going public after 1992 & 0.37 & 0.23 & 1 \\
\hline Median market value & $\$ 769$ million & $\$ 820$ million & $\$ 632$ million \\
\hline Number of companies & 3140 & 1246 & 1161 \\
\hline
\end{tabular}

Notes: Summary statistics for the entire sample of companies (column 1) and two relevant subgroups of companies - companies not incorporated in Delaware (column 2) and companies that went public after the passage of all Control Share Acquisition (CSA) and Business Combination (BC) statutes (column 3). Rows present the number of companies in the group relative to the total number of companies, the number of companies benefitting from CSA or BC competition (including companies that obtain such protection directly via passing their own amendment), the proportion of the total number of companies that are incorporated in states with CSA or BC statutes that allow opt-out via bylaw amendment or only via charter amendment, the proportion of companies in each sample covered by poison pill, the median market value of the companies and the total number of companies. 
Table 2 examines the summary statistics in greater detail to demonstrate several findings of interest. First, note that opt-out rates for all statutes are low. This is particularly so for business combination and fair price statutes, which have opt-out rates below 5\%. Protection rates for companies not covered by antitakeover statutes, by contrast, are extremely low, suggesting that the antitakeover provisions are not retained exclusively because they are efficient for all companies. Thus, antitakeover protections represent a paradigmatic case for the benefits of increasing shareholder power. State law entails a seemingly undesirable default law - a rule that depresses market value and that companies would not enact on their own - that is unlikely to be changed by management because it benefits management. Greater shareholder power should enable shareholders to alter the undesirable antitakeover provisions without managerial interference, causing substantial differences in governance between bylaw and charter states.

\section{Table 2}

Antitakeover Statute Coverage Rates

\begin{tabular}{lcccc}
\hline & $\begin{array}{c}\text { Control share acquisition statutes } \\
\text { (proportion of firms in each } \\
\text { category enjoying } \\
\text { CSA protection) }\end{array}$ & $\begin{array}{c}\text { Business combination statutes } \\
\text { (proportion of firms in each } \\
\text { category enjoying } \\
\text { BC protection) }\end{array}$ \\
\hline $\begin{array}{l}\text { Opt-out } \\
\text { mechanism }\end{array}$ & all firms & non Delaware firms & all firms & non Delaware firms \\
Charter & $81.7 \%$ & $81.7 \%$ & $96.8 \%$ & $96.8 \%$ \\
amendment only & $(4.0)$ & $(4.0)$ & $(1.1)$ & $(1.1)$ \\
Bylaw or charter & $87.6 \%$ & $87.6 \%$ & $96.4 \%$ & $95.7 \%$ \\
amendment & $(1.4)$ & $(1.4)$ & $(0.3)$ & $(0.8)$ \\
No statute & $0.1 \%$ & $0.8 \%$ & $5.0 \%$ & $5.0 \%$ \\
& $(0.08)$ & $(0.4)$ & $(1.3)$ & $(1.3)$ \\
\hline
\end{tabular}

Notes: Antitakeover statute coverage rates for firms characterized by the intersection of the row and column headings. Standard errors of the coverage rate estimate are in parentheses.

Table 2 fails to support the notion that increased shareholder power, in the form of bylaw altering rules rather than charter amendment altering rules, changes outcomes. Companies opt out of business combination statutes at nearly identical (low) rates in both charter amendment and bylaw amendment states. This result is not sensitive to the inclusion or exclusion of Delaware companies. Companies required to opt out via charter amendment or board directed bylaw amendment opt-out of CSA protection at higher rates than companies in shareholder bylaw opt-out states. ${ }^{16}$

16 Note that the high opt-out rate for board passed bylaw amendments reflects the inclusion within this category of Pennsylvania, which passed a notoriously restrictive antitakeover law that prompted many companies to opt out (BEBCHUCK AND COHEN [2003]). 
This again fails to support the hypothesis that greater shareholder power should lead to higher opt-out rates from antitakeover statutes.

\section{Regression Specification}

While the summary statistics in Tables 1 and 2 suggest that different altering rules and degrees of shareholder power have little effect on outcomes, these statistics should be viewed warily. Selection bias and omitted variable bias may cause systematic differences in antitakeover provision opt-out rates between companies in different states. Simply put, companies in states with one type of altering rule may be systematically different from companies in states with a different altering rule. If this is the case, then differences in antitakeover provision adoption rates cannot be attributed to differences in corporate laws, but might be due to these other differences.

This concern, while real, should not be overstated. If the effect of shareholder power is sufficiently large, then it should be detectable in spite of the endogeneity problem. The increase in protection rates associated with the enactment of a state antitakeover default law, for example, is so large that it is unlikely that any plausible selection effect could have caused it or have made it disappear. Even if the summary statistics do not prove a causal effect, the finding of no association between shareholder power and governance arrangements should shift the burden of proof regarding the impacts of shareholder power.

In addition, there are several reasons to think that the endogeneity problems described above may not be particularly severe. First, selection of state of incorporation is not as fluid as one might expect. Companies either choose Delaware or their "home" state - where their headquarters is located (DAINES [2002]). Thus, companies that stay in their home state are defined more by inertia than a desire to select the corporate law that suits their manager's interests. Second, many of the statutes were passed to protect one particular company from a takeover. For example, Minnesota's control share acquisition and business combination statutes were developed by Minnesota corporation Dayton Hudson to prevent a hostile takeover, and was amended when the provisions proved to be an obstacle to a friendly merger for Tonka, another Minnesota company (ISAACS [2004]). Many other state antitakeover statutes have similar origins. ${ }^{17}$ The statutes were therefore targeted at specific companies rather than being related to the average corporation from the state. Therefore, the choice of altering rule for each statute is more likely to reflect the idiosyncratic needs of an individual company than it is to reflect systematic differences between the types of companies incorporated in the state. ${ }^{18}$

17 See IsAACS [2004] for a discussion of the history behind many of the statutes.

18 The states in which such idiosyncratic passage was most salient were identified and the regression models described below were applied exclusively to these states, with little change in outcomes. 
Third, selection effects should bias the results in favor of finding a difference caused by altering rules, rather than no difference. If companies hoping to reject shareholder opinion choose states of incorporation that are likely to restrict shareholder power with restrictive altering rules such as a requirement for charter amendments, then comparing opt-out rates for different altering rules should reveal a large apparent effect. Opt-out rates in charter amendment states should be lower for two reasons: (1) the actual effect of the differential altering rules and (2) the selection effect caused by companies choosing states that fit their preferences. Thus, the observed impact of the difference in altering rules should be upwardly biased.

Fourth, the paper tries several different specifications to further reduce the potential for omitted variables and selection effects to bias the results. The regressions are restricted to companies in states with antitakeover default laws. The basic linear probability model is: ${ }^{19}$

$$
Y_{c s}=\alpha+X_{c s} \beta+\delta \text { altering_rule }{ }_{s}+\varepsilon_{c s},
$$

where $Y_{c s}$ indicates whether or not company $c$ has opted out of a particular antitakeover protection of state $s\left(=1\right.$ if the company has opted out), $X_{c s}$ is a vector of control variables, including company size, profitability, census division dummies (because the source of variation is state level, state controls cannot be used in this specification), debt levels, industry dummies, a dummy for whether the company went public before or after the passage of the statute, and, in some specifications, measures of other governance features, ${ }^{20}$ such as the presence of a poison pill or staggered board, the existence of golden-parachute provisions, a measure of directorial independence, the existence of secret balloting, and the existence of cumulative voting provisions. Delaware corporations are excluded from all specifications. The primary variable of interest is altering_rule ${ }_{s}$ - a dummy variable indicating whether the company is located in a state with a bylaw opt-out altering rule $(=1)$. Because of incredibly high correlation for governance terms within companies (over $99 \%$ of companies retain their initial choice on opting in or out of the statutes throughout the time period), I present regressions with only one observation per company (firm averages) to avoid overstating standard errors. ${ }^{21}$ Only companies in states with antitakeover statutes that can be altered by bylaw or charter amendment are included in the regressions.

While this specification controls for many possible confounding factors, it remains possible that companies in states allowing opt-out via bylaw amendment are unobservably different from companies in states requiring charter amendments to opt out. To address this issue, I focus on the difference between firms that went

19 Applying a logit specification has little impact on the results. I prefer the linear probability model in this case because it is easier to interpret.

20 Poison pills and staggered board controls are not included in most specifications due to the fact that these might act as substitutes for the antitakeover protections studied here.

21 This corresponds to the "between" estimator of a panel data random effects model. See JOHNSTON AND DiNARDO [1997, pp. 392f.]. 
public before the state statutes were passed ("midstream companies") and firms that went public afterwards. The choice of altering rule should have a much larger affect on midstream companies than other companies. Because companies going public after the statute's passage internalize the cost of the antitakeover provisions, they should opt out of the statutes whenever they are inefficient, regardless of the altering rule. Placing this assumption into a regression framework,

$$
\begin{aligned}
Y_{c s}= & \alpha+X_{c s} \beta+\sigma \text { midstream_dummy } \\
& +\gamma \text { altering_rule }+\delta \text { altering_rule }_{s} \times \text { midstream_dummy } \\
& +\varepsilon_{c s},
\end{aligned}
$$

where midstream_dummy ${ }_{c}$ is a dummy variable indicating if a firm was already public when the antitakeover statute was passed. Theory predicts that the coefficient on this dummy variable will be positive, as firms that go public after the statutes passage have a strong financial incentive to opt out only if the statute hurts value. altering_rule ${ }_{s} \times$ midstream_dummy $_{c}$ is an interaction term between being in an altering rule state and being a midstream company when the statute was passed have been added to the original specification. If altering rules are important for midstream firms, then the coefficient on this interaction term should be statistically significant, reflecting the fact that the difference in altering rules is most salient for midstream firms. If all firms (midstream and non-midstream) in different altering rule states are unobservably different in their likelihood to have antitakeover protections, then

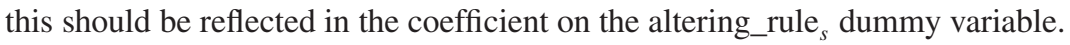

\section{Results and Interpretation}

Table 3 presents the results of several regression specifications estimating the impact of various factors on the likelihood of opting out of a business combination statute. The results are broadly similar across all the specifications. With the exception of the controls for industry, year, and census division, very few of the control variables for financial performance or type of firm are statistically or practically significant. ${ }^{22}$

The results fail to provide considerable support for the notion that altering rules placing more power in the hands of shareholders lead to more efficient arrangements. In the cross-sectional regressions corresponding to equation (1), (columns 2 and 3), the ability to opt out of a statute via bylaw is not associated with any change in the probability of opting out of an antitakeover statute relative to needing a charter amendment for opt-out. This non association between shareholder power and optout rate remains the case after controlling for many factors, such as a firm's industry and size.

As described above, the simple cross-sectional regressions do not control for unobservable differences in propensity to opt out of antitakeover statutes that are

22 Restricting the regression results presented below to firms making losses, who should be the most likely to resist antitakeover protections, does not appreciably alter the results - in these alternative specifications (available on request) the ability to opt out via bylaw is not associated with a statistically or practically significant change in opt-out rates. 
Table 3

Regression Outcomes: Business Combination Statutes

\begin{tabular}{|c|c|c|c|c|c|}
\hline Coefficient & Base case & $\begin{array}{c}\text { Control } \\
\text { variables }\end{array}$ & $\begin{array}{l}\text { Base case } \\
\text { with } \\
\text { interaction } \\
\text { term }\end{array}$ & $\begin{array}{c}\text { Control } \\
\text { variables } \\
\text { and } \\
\text { interaction } \\
\text { term }\end{array}$ & $\begin{array}{l}\text { Excludes } \\
\text { Delaware }\end{array}$ \\
\hline (1) & (2) & (3) & (4) & (5) & (6) \\
\hline $\begin{array}{l}\text { Allows opt-out } \\
\text { via bylaw }\end{array}$ & $\begin{array}{l}0.0055 \\
(0.010)\end{array}$ & $\begin{array}{c}-0.0061 \\
(0.019)\end{array}$ & $\begin{array}{l}-0.036 \\
(0.023)\end{array}$ & $\begin{array}{l}-0.039 \\
(0.033)\end{array}$ & $\begin{array}{c}-0.063^{*} \\
(0.034)\end{array}$ \\
\hline Midstream firm & & $\begin{array}{c}-0.028^{* * *} \\
(0.010)\end{array}$ & $\begin{array}{c}-0.071^{* *} \\
(0.025)\end{array}$ & $\begin{array}{c}-0.064^{* *} \\
(0.031)\end{array}$ & $\begin{array}{c}-0.062^{* *} \\
(0.025)\end{array}$ \\
\hline $\begin{array}{l}\text { Bylaw opt-out } \\
\text { interacted with } \\
\text { midstream status }\end{array}$ & & & $\begin{array}{l}0.046^{*} \\
(0.026)\end{array}$ & $\begin{array}{c}0.035 \\
(0.032)\end{array}$ & $\begin{array}{c}0.050 \\
(0.034)\end{array}$ \\
\hline $\begin{array}{l}\text { Financial } \\
\text { controls }\end{array}$ & no & yes & no & yes & Yes \\
\hline $\begin{array}{l}\text { Industry } \\
\text { controls }\end{array}$ & no & yes & no & yes & Yes \\
\hline $\begin{array}{l}\text { Census division } \\
\text { controls }\end{array}$ & no & yes & no & yes & Yes \\
\hline Observations & 2728 & 1546 & 2715 & 1546 & 561 \\
\hline$R^{2}$ & 0.000 & 0.040 & 0.008 & 0.028 & 0.040 \\
\hline
\end{tabular}

Notes: Dependent variable equals one if company is covered by a business combination statute and equals zero if the company is not covered. Standard errors in parentheses. ${ }^{* * *} p<0.01,{ }^{* *} p<0.05,{ }^{*} p<0.1$. Financial Controls include log of market value, $\log$ of annual income, market-to-book ratio, and debt-to-equity ratio. Columns 3, 5, and 6 include many fewer observations because of the imprecise matching between Compustat data and IRRC data.

correlated with the altering rule of a firm's state of incorporation. ${ }^{23}$ The simple crosssectional regressions, however, provide support for the assumption that underlies the specification in equation (2) - midstream firms are less likely to opt out of their states' antitakeover statutes, suggesting that the choice of altering rule is most important for midstream firms. This enables equation (2) to control for unobserved differences using firms that go public after the passage of the statute.

Columns 4, 5, and 6 of Table 3, which present various specifications corresponding to equation (2), suggest that firms in bylaw opt-out states are generally less likely

23 The presence of statutes is least likely to be endogenous to the type of corporations incorporated in the state when the statute was passed to protect one company specifically. Regressions focusing on these states show no discernible impact of optout rules on governance. 
Table 4

Regression Outcomes: Control Share Acquisition Statutes

\begin{tabular}{lcccc}
\hline Coefficient & Base case & $\begin{array}{c}\text { Control } \\
\text { variables }\end{array}$ & $\begin{array}{c}\text { Base case } \\
\text { with } \\
\text { interaction } \\
\text { term }\end{array}$ & $\begin{array}{c}\text { Control } \\
\text { variables and } \\
\text { interaction } \\
\text { term }\end{array}$ \\
\hline Allows opt-out via & $(1)$ & $(2)$ & $(3)$ & $(4)$ \\
bylaw & 0.028 & 0.017 & 0.049 & -0.0025 \\
Midstream firm & $(0.038)$ & $(0.046)$ & $(0.080)$ & $(0.11)$ \\
& & 0.033 & -0.0129 & 0.016 \\
Bylaw opt-out & & $(0.042)$ & $(0.084)$ & $(0.11)$ \\
interacted with & & & -0.027 & 0.021 \\
midstream status & & & $(0.091)$ & $(0.12)$ \\
Financial controls & no & yes & no & Yes \\
Industry controls & no & yes & no & Yes \\
Census division controls & no & yes & no & Yes \\
Observations & 634 & 428 & 634 & 428 \\
$R^{2}$ & 0.001 & 0.144 & 0.003 & 0.143 \\
\hline
\end{tabular}

Notes: Dependent variable equals one if company is covered by a control share acquisition statute and equals zero if the country is not covered. Standard errors in parentheses. ${ }^{* * *} p<$ $0.01,{ }^{* *} p<0.05,{ }^{*} p<0.1$. Financial Controls include log of market value, log of annual income, market-to-book ratio, and debt-to-equity ratio. Columns 3, 5, and 6 include many fewer observations because of the imprecise matching between Compustat data and IRRC data.

to opt out of antitakeover statutes than firms in charter opt-out states, even after controlling for other factors. Firms that went public after the passage of business combination statutes from states with bylaw opt-out are from 3-6\% (depending on the specification) less likely to opt out than firms in charter opt-out states, in spite of the fact that all firms going public after the passage of the statute have strong financial incentives to opt out regardless of the altering rule in their state of incorporation.

After controlling for this differential propensity to opt out of business combination laws, there is mixed evidence for the thesis that increasing shareholder power has impacts. Midstream firms in bylaw opt-out states (who have greater power) are approximately $3.5 \%-5 \%$ (depending on the specification) more likely to opt out of business combination protection than similar firms that must opt out via charter. This difference is noteworthy, and provides some support for the argument that shareholder's use of shareholder power to alter governance arrangements in shareholder's favor. Two important caveats must be emphasized, however. First, 
the increase in opt-out percentage is not statistically significant at the 5\% level (though in some of the specifications it is significant at the $10 \%$ level). Second, an increase of $4 \%$ in opt-out rates, while noteworthy and large compared to overall low opt-out rates of approximately 5\%, is very small compared to the impact of having a statute at all. In earlier work, I demonstrated that the total absence of a business combination statute lowers coverage rates for midstream firms by over $90 \%$, while the existence of a business combination statute as a non-default menu option rather than a default law reduces coverage rates by $23 \%$ (LISTOKIN [2009]). The increase in opt-out rates associated with increased shareholder power pales in comparison with these numbers.

The results for control share acquisition statutes (Table 4) provide further evidence that increased shareholder power is at best a small factor in determining governance arrangements. The ability to opt out via bylaw is not associated with any significant change (in both the statistical and practical senses) in the number of firms opting out of CSA protection. This non association holds true for midstream firms as well as all firms. Indeed, almost no variables of any sort, including financial and industry controls, are associated with CSA opt-out in any significant manner. The non predictability of CSA protection is consistent across a range of different regression specifications, as demonstrated in Table 4.

\section{Conclusion}

If shareholder power is an important input into corporate governance arrangements, as some have argued, then large differences in shareholder power with respect to important governance measures should lead to differences in governance. In particular, shareholder's ability to unilaterally opt out of prominent state antitakeover statutes should lead to significantly higher opt-out rates relative to companies where shareholders did not enjoy such power. The results presented in this paper, however, indicate that this difference in power is associated with little, if any, changes in governance. Relative to the impact of passing an antitakeover statute, enabling greater shareholder power in the application of the statute has very little impact. ${ }^{24}$

It should also be emphasized, however, that the increased shareholder power associated with the ability to opt out via bylaw was not associated with widespread manipulation of shareholder power to further narrow interests such as those of unions or other interest groups.

In total, these results suggest that the heated predictions and emotions associated with the debate regarding shareholder power are overwrought. Taken alone, this instance of increased shareholder power made very little difference. The findings, however, should not be taken to mean that shareholder power is irrelevant. In addition to the usual caveats about endogeneity limiting causal inference, it is also possible to view increased shareholder power as a necessary, but not a sufficient condition for

24 While it is possible that merely the threat of bylaw opt-out alters corporate behavior, the data gives no hint of such an effect. 
improved governance. That is, increasing shareholder power without making other reforms to governance may not have an impact, but a failure to increase shareholder power may prevent the benefits of other corporate governance reforms, such as increased shareholder activism, from being realized.

\section{References}

Bainbridge, S. M. [1992], “Interpreting Nonshareholder Constituency Statues,” Pepperdine Law Review, 19, 971-1025.

- [2006], "Director Primacy and Shareholder Disempowerment," Harvard Law Review, $119,1735-1758$.

Bebchuk, L. [2005], “The Case for Increasing Shareholder Power," Harvard Law Review, $188,836-914$.

- AND A. COHEN [2003], "Firms' Decisions where to Incorporate," The Journal of Law \& Economics, 46, 383-422.

- AND A. HAmdani [2002], "Optimal Defaults for Corporate Law Evolution,” Northwestern University Law Review, 96, 489-519.

Buxbaum, R. M. [1985], "The Internal Division of Powers in Corporate Governance," California Law Review, 73, 1671-1734.

CoffEe JR., J. C. [1997], "The Bylaw Battlefield: Can Institutions Change the Outcome of Corporate Control Contests?" University of Miami Law Review, 51, 605-621.

DAINES, R. [2002], "The Incorporation Choices of IPO Firms," New York University Law Review, 77, 1559-1610.

DeConinck, R. [2005], "Do Firms Sufficiently Opt-Out of Non-Mandatory Laws? Evidence from Business Combination Statues," New York University Law School Working Paper.

Dent JR., G. W. [1989], "Toward Unifying Ownership and Control in the Public Corporation," Wisconsin Law Review, 1989, 881-924.

EASTERbrooK, F. H., AND D. R. Fischel [1991], The Economic Structure of Corporate Law, Harvard University Press: Cambridge, MA.

Gompers, P., J. Ishit, AND A. Metrick [2003], "Corporate Governance and Equity Prices," The Quarterly Journal of Economics, 118, 107-155.

HAmermesh, L. A. [1998], "Democracy and Stockholder-Adopted By-Laws: Taking Back the Street?" Tulane Law Review, 73, 409-493.

IsAACS, J. D. [2004], State Takeover Laws, Investor Responsibility Research Center: New York.

Johnston, J., AND J. DiNARdo [1997], Econometric Methods, McGraw-Hill: New York.

KARPOFF, J. M., AND P. H. MALATESTA [1989], "The Wealth Effects of Second Generation Takeover Legislation,” Journal of Financial Economics, 25, 291-322.

Listokin, Y. [2009], "What do Corporate Default Rules and Menus Do? An Empirical Examination," Journal of Empirical Legal Studies, 6, 279-308.

Romano, R. [1993], The Genius of American Corporate Law, AEI Press: Washington, D.C.

Yair Listokin

Yale Law School

P.O. Box 208215

New Haven, CT 06520-8215

U.S.A.

E-mail:

yair.listokin@yale.edu 